УдК 616.314.18-002.4+575.113

DOI 10.11603/2311-9624.2016.4.7232

(С). І. Хомик, Г. М. Мельничук, Л. Є. Ковальчук

ДВНЗ «Івано-Франківський національний медичний університет»

\title{
Перспективи дослідження спадкової схильності до виникнення і розвитку генералізованого пародонтиту
}

Резюме. Проведено огляд і аналіз літератури за 2004-2016 роки та описано методики досліджень, які використовуються при вивченні генетичної схильності до генералізованого пародонтиту (ГП), зокрема клініко-генеалогічний, близнюковий, дерматогліфічний та цитогенетичний методи. Проаналізовано можливості застосування нових методів дослідження маркерів генетичного обтяження на доклінічному етапі розвитку ГП, зокрема при поєднаному дослідженні, яке включає вивчення родоводів, епігенетичних, морфоденситометричних та імуноцитогенетичних механізмів розвитку ГП.

Ключові слова: генералізований пародонтит; функціональний стан генотипу; метафазний аналіз; морфоденситометрія; мікроядерний індекс.

\section{М. И. Хомик, Г. М. Мельничук, Л. Е. Ковальчук}

ГВУЗ «Ивано-Франковский национальный медицинский университет»

\section{Перспективы исследования наследственной предрасположенности к возникновению и развитию генерализированного пародонтита}

Резюме. Проведены обзор и анализ литературы с 2004 по 2016 годы и описаны методики исследования, использующиеся при изучении генетической предрасположенности к генерализованному пародонтиту (ГП), в частности клинико-генеалогический, близнецовый, дерматоглифический и цитогенетический методы. Проанализированы возможности применения новых методов исследования маркеров генетической предрасположенности на доклиническом этапе развития ГП, в частности при одновременном исследовании, включающем изучение родоводов, эпигенетических, морфоденситометрических и имуноцитогенетических механизмов развития ГП.

Ключевые слова: генерализированный пародонтит; функциональное состояние генотипа; метафазный анализ; морфоденситометрия; микроядерный индекс.

\section{I. Khomyk, H. M. Melnychuk, L. Ye. Kovalchuk}

Ivano-Frankivsk National Medical University

\section{Prospects for investigation of hereditary predisposition to the appearance and development of generalized periodontitis}

Summary. Literature review from 2004 to 2016 years was performed. It was described methods of investigation that had been used in the study of genetic predisposition to generalized periodontitis (GP) in particular: clinic-genealogical, „twins” - method, dermatology, cytogenetic. It was analyzed the prospect of using a novel research methods of genetic markers burden on the preclinical stage development of the GP in particular: the complex investigation of the family trees, epigenetics, morphodensitometric and immunogenetic diagnostic criteria GP development.

Key words: generalized periodontitis; functional state of genotype; metaphasic chromosomal analysis; morphodensitometric; micronuclear indices. 
Хвороби пародонта є однією з найважливіших проблем сучасної стоматології. Значна поширеність їх, велика втрата зубів у пацієнтів, несприятливий вплив вогнищ пародонтальної інфекції на організм зумовлюють необхідність удосконалення комплексної діагностики та лікування хвороб пародонта [1]. За даними в003, поширеність захворювань пародонта в дорослих у віці 35-44 р. становить у цілому світі 94,3 \% [2], а в Україні, залежно від регіону та віку обстежених, - 85-95 \% [3]. Отже, питання виникнення і розвитку ГП є актуальними та потребують подальшого вивчення.

Встановлено, що причиною розвитку ГП $€$ фактори екзогенного та ендогенного походжень. Із екзогенних чинників важливе значення мають зубні відкладення, мікрофлора ротової порожнини, шкідливі звички, травматична оклюзія, неякісні ортопедичні та ортодонтичні конструкції [4]. Проте пацієнти часто хворіють на ГП без явно виражених екзогенних чинників. Цей факт є свідченням того, що етіопатогенез захворювань пародонта залежить також від ендогенних чинників, зокрема соматичних і перенесених інфекційних захворювань, гіповітамінозів, порушень обміну речовин тощо [4]. Як мультифакторне захворювання, ГП розвивається також і під впливом такого ендогенного чинника, як спадковий. При цьому запальна та імунна реакції, які мають важливе значення у патогенезі ГП, реалізуються в конкретних умовах зовнішнього середовища і залежать від впливу екзогенних чинників [5]. На сьогодні відомо, що провідна роль у виникненні й розвитку ГП належить мікробному фактору, проте при утворенні мікробної бляшки в одних розвивається хвороба, в інших - ні, що залежить від відповіді макроорганізму на дію мікробного фактора. Це спричинено генетичною конституцією, що детермінує реакцію кожної особи на екзо- й ендогенні чинники, які призводять до розвитку ГП. Отже, будь-яка хвороба (фенотип) зумовлена: генотипом (набір генів), середовищем та біологічними взаємодіями між ними [6].

Спостереження протягом тривалого часу за пацієнтами, які хворіють на ГП, дозволило виділити два варіанти його перебігу: сприятливий (без генетичної схильності до хвороби) та несприятливий (у пацієнтів з обтяженою спадковістю до розвитку ГП) [8]. $€$ переконливі дані про наявність одного або більше генів, які відповідають за успадкування ГП. Проте питання про тип успадкування хвороб пародонта на сьогодні залишається невирішеним [6]. В останній час спостерігається зростання кількість пацієнтів, які хворіють на агресивний пародонтит. У низці наукових досліджень виявлена закономірність виникнення його у членів однієї сім’ї, що свідчить про вплив генетичного чинника на розвиток цієї патології [9]. Отже, для ранньої діагностики мультифакторних захворювань, у т. ч. ГП, та прогнозування ймовірності їх розвитку вкрай важливим $\epsilon$ встановлення маркерів генетичної обтяженості на доклінічному етапі захворювання. Для вирішення цього завдання необхідні нові методологічні підходи, що базуються на сучасних інформаційних технологіях [10].

Із метою вивчення ролі спадкових чинників у виникненні ГП проводять комплексне генетичне дослідження, що включає клініко-генеалогічний, дерматогліфічний та цитогенетичний методи дослідження [8]. Значна роль генетичного компоненту в розвитку ГП однозначно доведена класичним для генетики людини методом дослідження близнюків. B Michalowicz та співавт. оцінили кілька параметрів, пов’язаних із пародонтитом (глибина пародонтальних кишень, пародонтальний індекс та індекс зубного нальоту), в 110 дорослих близнюків і дійшли до висновку, що від 38 до 82 \% популяційної мінливості цих параметрів є генетично зумовленими [9].

На підставі дискримінантного і факторного аналізу комплексу дерматогліфічних паказників визначено найінформативніші ознаки ГП (домінуючі гребеневі рахунки і малюнки на пальцях рук, малюнки у міжпальцевих проміжках, гіпотенарі й тенарі, закінчення ліній долоні А, В, С, Д, згинальні складки долоні). Наявність шести з них дає змогу проводити доклінічну діагностику ГП [6]. Крім того, вивчення дерматогліфічних показників у разі ГП дозволило виділити деякі особливості дерматогліфічного малюнка у пацієнтів залежно від того, обтяжений анамнез за даним захворюванням, чи ні [8].

Генетична схильність до розвитку ГП підтверджується також особливостями розподілу антигенів груп крові систем AB0 i Rh. Зокрема, встановлено, що у хворих на ГП чоловіків група крові АВ зустрічалася у 2,72 раза рідше, ніж у здорових. У разі ГП в жінок за антигенами груп крові АВ0 вірогідних відмінностей від здорових не виявлено [6]. Встановлено асоціативні зв'язки між ГП та антигенами груп крові систем АВ0, 
Rh, HLA (I класу), які визначають специфіку взаємодії спадкових і середовищних чинників у формуванні ГП. Маркером спадкової схильності до ГП є наявність групи крові A (II), HLAантигенів B8, Cw2 в осіб обох статей [8].

Проте найдоступнішим та найінформативнішим методом вивчення ролі генетичного фактора в етіології будь-якої хвороби i, зокрема гастроентерологічної патології, $\epsilon$ клініко-генеалогічний аналіз родоводів [11]. За результатами клініко-генеалогічного аналізу пацієнтів із дефектами зубних рядів встановлено генетичну схильність до ГП у $(25,00 \pm 8,84) \%$ чоловіків та в $(40 \pm 9,80) \%$ жінок [12]. За генеалогічними даними, у пацієнтів без обтяженої стосовно ГП спадковості число хворих було мінімальним у віковій групі 20-29 років (16,7 \%), а максимальним - після 40 років (45,0 \%). Серед пацієнтів 3 обтяженим щодо ГП анамнезом у віці до 20 років виявлено 11,7 \% хворих осіб, а найбільшу кількість уражених відмічено у віковій групі 30-39 років - 32,9 \% [8]. Отже, клініко-генеалогічний метод дослідження є обгрунтованим, актуальним і доцільним як такий, що дозволить виявити фенотип або маркерний профіль захворювання, виділити групу генетично обтяжених осіб [10].

Доведено, що всі клітини людини містять однакову генетичну інформацію, яка в процесі розвитку і життедіяльності зчитується вибірково: одночасно всі гени ніколи не працюють. Таким чином існує вибірковість включення або виключення певних генів при збереженні решти генетичної інформації. Вибірковість зчитування інформації контролюють епігенетичні (що дослівно означає «за межами звичайної генетики») механізми. Під епігенетичною мінливість розуміють зміни активності (експресії) генів без змін самих генів, тобто первинної послідовності нуклеотидів у днК. ці зміни відбуваються в структурі хроматину і вони потенційно зворотні. Встановлення механізмів епігенетичної регуляції генної активності необхідне не лише для розуміння основ онтогенезу, але й причин виникнення різних мультифакторних захворювань [13].

Загальний стан організму залежить від активності метаболічних процесів кожної окремої клітини. До патологічних змін на клітинному рівні може призвести будь-яке захворювання. Найперше це виявляеться у порушенні процесів реалізації спадкової інформації геному, що, у свою чергу, спричиняє зміни функціонального стану. Характер і ступінь конденсації хроматину в інтерфазних ядрах соматичних клітин (букальних епітеліоцитах) відображають регуляцію роботи генів на рівні хромосом [11].

Останні досягнення в галузі молекулярної генетики доводять, що механізми, які контролюють епігенетичну регуляцію експресії генів, зумовлені динамікою ремоделювання хроматину і метилювання днК, тобто функція більшої частини генів пов'язана з деталями будови хроматину, який є цитологічним відображенням функції генотипу. Хроматин ядра розділений на дві фракції: більш активна дисперсна, деконденсована фракція, яка дозволяє транскрипцію (матричний синтез РНК - мРНК) - еухроматин (EX) і неактивна, конденсована фракція, яка забороняе транскрипцію - гетерохроматин (ГХ). Співвідношення між EX і ГX, тобто індекс хроматизації (IX), змінюється залежно від функціональної активності клітин. Вказаний індекс відображає середню для індивіда величину експресибельності генотипу [14] та вважається морфологічним критерієм функціональної активності клітин [6]. Крім фракцій хроматину в інтерфазних ядрах є ще одна структура - ядерця. Ці органели відповідають за синтез рРНК і їх структура та кількість відображають рівень метаболізму клітини в цілому. Ядерцевий (нуклеолярний) індекс (ЯI, НI) визначається через кількість ядер, що мали ядерця, відносно всіх вивчених ядер. ЯІ може бути відображенням i синтезу білка, й активності епігенетичних механізмів його контролю [14].

Із показниками ЯІ тісно пов'язане таке поняття як морфологічно змінені (патологічні) ядра (МЗЯ, ПЯ) клітин, що є своєрідним індикатором прояву патологічних процесів у різних органах і системах. Відношення кількості незмінених ядер епітеліоцитів до числа ядер зі зміненою оболонкою є найбільш показовим критерієм ефективності лікування [6].

Ще одним важливим показником функції генотипу $\epsilon$ індекс гетеропікнотичної $\mathrm{X}$-хромосоми (статевий хроматин (СХ), тільця Барра), який розцінюється як показник регуляції реалізації генетичної інформації, а ступінь ії̈ конденсації свідчить або про нормальну експресію генів, або про порушення цього процесу. Інактивація X-хромосоми здійснюється за рахунок тривалого перебування іiї у спіралізованому стані, цитологічним проявом якого є тільце Барра. При різних патологічних станах зменшується число барпозитивних клітин. Як наслідок цього, з'являється 
можливість мобілізації додаткової генетичної інформації, спрямованої на підтримання гомеостазу на рівні макроорганізму чи окремих тканин. Інактивація двох X-хромосом явище летальне, тому зменшення показника CX у клітинах органа, ураженого патологічним процесом, може свідчити про ступінь тяжкості захворювання. Зростання показника СХ у чоловіків зрілого віку в 1,31 раза, порівняно $з$ такими в юнаків, та зниження CX у жінок зрілого і похилого віку визначає вікове порушення оптимальних механізмів контролю диференційної активності генів [14].

3 результатів цитологічних досліджень генетичних маркерів структурно-функціонального стану генотипу (ФСГ) соматичних клітин (букальних епітеліоцитів) у хворих на ГП і пародонтоз виявлено порушення процесів реалізації спадкової інформації на клітинному рівні. У чоловіків знижувалися показники індексів EX, IX, HI і підвищувався показник CX та кількість МЗЯ. У жінок за індексами ЕX, IX, HI та МЗЯ були схожі закономірності, проте спостерігалося зниження індексу СX [6, 7].

Динаміка показників ФСГ букальних епітеліоцитів слизової оболонки ротової порожнини (СОРП) та нейтрофільних гранулоцитів крові (НГК) вивчалася у разі ГП [15] та протезного стоматиту [12]. Підтверджено встановлене раніше [7] порушення процесів реалізації спадкової інформації за ГП на клітинному рівні, що проявляється зменшенням IX, ЯІ та збільшенням кількості МЗЯ незалежно від статі, а також зниженням індексу CX у жінок і зростанням його в чоловіків. Виявлені кореляційні взаємозв'язки між IX, ЯІ і МЗЯ епітеліоцитів СОРП та НГК у здорових осіб, а також у хворих на ГП вказують на збереження функціональної єдності спадкового апарату різних соматичних клітин [16]. Доведено, що цитологічні зміни ФСГ епітеліальних клітин СОРП характерні для кожного виду протезного стоматиту і залежать від статі: у чоловіків достовірно зростає IX при контактному протезному стоматиті, ЯI - при алергійному і комбінованому протезному стоматиті; у жінок - вірогідна активація ЯІ та збільшення ПЯ при всіх видах протезних стоматитів, що відображає глибину порушень метаболізму клітини та ступінь тяжкості перебігу протезного стоматиту у хворих. Вірогідні зміни відбуваються і в НГК - зменшується показник ЯІ у всіх хворих на протезний стоматит та істотно знижується СХ у жінок із комбінованим протезним стоматитом [12].
Відомо, що ГП є дистрофічно-запальним захворюванням, тому в його розвитку значну роль відіграють імунокомпетентні клітини лімфоцити. Їх субпопуляції активуються під впливом певних цитокінів [6], які діють на фактори активації транскрипції цих клітин, що призводять до відповідної регуляції експресії генів. Однак крім цього в регуляторних процесах функцій лімфоцитів вагоме значення мають епігенетичні модифікації ступеня компактизації ядерного хроматину, тому розуміння епігенетичних механізмів диференціації лімфоцитів дозволить у майбутньому запобігти їх пошкоджувальному впливу та сприяти утворенню корисних субпопуляцій [17]. Порівняння ФСГ різних інтерфазних клітин $є$ перспективним, що доводить існування фундаментальних властивостей спадкового апарату - його цілості та універсальності [12]. Отже, дослідження лімфоцитів у хворих на ГП для встановлення деяких закономірностей і виявлення кореляційних зв'язків між показниками ФСГ букальних епітеліоцитів і лімфоцитів доцільне та дозволить з'ясувати деякі механізми патогенезу ГП.

Новим методом дослідження, який ще не використовувався у стоматології, є морфоденситометричний аналіз показників ядер епітеліоцитів СОРП: морфометричних (співвідношення площі ядра до площі клітини та коефіцієнта форми ядра до коефіцієнта форми клітини) та спектрометричних (інтегральна, мінімальна, максимальна оптичні щільності хроматину та діапазон мінливості оптичної щільності). Морфоденситометричне дослідження дає можливість встановити компенсаторні зміни на клітинному рівні та оцінити функціональний стан спадкового апарату [18]. Для вивчення кореляцій морфоденситометричних показників ядер епітеліоцитів 3 епігенетичними ефектами необхідно аналізувати індекси ФСГ - IX, CX та ПЯ з позицій формування цитофенотипу [18]. Зокрема, у пацієнтів із виразковою хворобою виявлено статистично вірогідні відмінності між цитогенетичними і морфометричними показниками, що є свідченням патогенетичних порушень при цій хворобі [11], а збільшення кількісних показників динаміки стану хроматину (інтегральна оптична щільність і співвідношення ГХ та ЕХ) та частота ПЯ відображають знижену здатність до репараційних процесів при хронічному обструктивному захворюванні легень. При цьому встановле- 
но, що зміни морфометричних і оптичних параметрів ядер епітеліоцитів залежать від стадії захворювання. Зареєстровано достовірне збільшення периметру ядер в 1,3 раза при третій стадії хвороби. Аналіз інтегральної оптичної щільності ядер засвідчив тенденцію до їі зниження у пацієнтів із легким перебігом хвороби. Отриманий результат можна вважати закономірним, оскільки збільшення об’єму ядра зумовлене набряковою реакцією каріоплазми на запальний процес [18].

Враховуючи спрямованість сучасної медицини на пріоритетність профілактичного підходу до вивчення норми і патології, що забезпечує діагностику і лікування хвороби на генному рівні з індивідуальним підходом і орієнтацією на конкретну людину, доцільно зосередити увагу на розробці комплексу критеріїв спадкової схильності до мультифакторних захворюваннь, зокрема ГП, що дозволить виділити групу генетично обтяжених осіб і забезпечить розробку адекватних профілактичних заходів на доклінічному етапі захворювання. Створення об’єктивного способу доклінічної діагностики ризику розвитку мультифакторного захворювання ще до виникнення клінічної симптоматики можливе завдяки вивченню особливостей хромосомного апарату, що відображає порушення імуногенетичного статусу людини, генетичну нестабільність і схильність до захворювання. Дане завдання можна вирішити завдяки вивченню інтегральних показників імуногенетичного статусу організму: асоціацій акроцентричних хромосом (AAX) у поєднанні з хромосомними абераціями (XА).

Вказані імуноцитогенетичні маркери у разі хронічного обструктивного бронхіту вивчала H. В. Чернюк і встановила суттєві зміни АAX та ХА при тяжкому ступені розвитку захворювання. Збільшення кількості АAX та ХА при хронічному обструктивному бронхіті засвідчує наявність імунодефіциту, оскільки саме він перешкоджає елімінації клітини з порушеним спадковим апаратом [19]. У стоматології метод метафазного аналізу вперше застосовано для вивчення спадкової схильності до протезних стоматитів. Установлено, що в нормі найбільшу здатність до утворення асоціацій мають хромосоми 21 (22,11 \%), 13 (21,62\%) і 14 (20,96 \%), а найменшу - 15 і 22 (18,04 і 17,27 \%). У випадку протезного стоматиту, на відміну від контролю, хромосоми 4 і 22 за асоціативною здатністю займають проміжне положення. Маркером алергійного протезного стоматиту можна вва- жати наявність пробілів у п'ятій хромосомі та зростання індексу D/G (співвідношення асоційованих хромосом груп D i G) та середньої частоти асоціацій на клітину [20]. Збільшення частоти АAX, особливо 14 і 22 хромосоми та XА можуть бути маркерами спадкової схильності до протезних стоматитів, що дозволяє здійснити доклінічну діагностику [12].

Інформативним дослідженням у цитогенетиці є також вивчення мікроядерного індексу (МЯ-індекс), який характеризує стан хромосомного апарату клітини. Мікроядро - патологічна структура, яка зазвичай утворюється в результаті неправильного клітинного поділу 3 відстаючих акроцентричних фрагментів, що виникають при розриві хромосом, та відстаючих хромосом. МЯ-індекс, який корелює 3 частотою ХА, вважають особливим показником стабільності геному, тому вивчення його актуальне при багатьох мультифакторних захворюваннях, зокрема і в разі ГП, а також при дослідженні мутагенного впливу на спадковий апарат як скринінг-тесту стану хромосомної нестабільності. Встановлено значне зростання Мя-індексу у хворих із тяжким перебігом хронічного обструктивного захворювання легень [21]. За допомогою кореляційного аналізу показників функціонального стану клітин СОРП до протезування у пацієнток, які мали незмінену СОРП, виявлено слабкі зворотні зв'язки між СХ та частотою МЯ. У чоловіків із дефектами зубних рядів доведено достовірний сильний від’ємний взаємозв'язок між ПЯ та МЯ. Ця кореляція зумовлена тим, що ПЯ не можуть вступати в мітотичний поділ тому, що містять мутації на хромосомному рівні. Отже, чим більше клітин з ПЯ є в СОРП, тим менша ймовірність утворення МЯ. Доведено взаємозв'язки середньої сили у чоловіків із дефектами зубних рядів до протезування та сильні - після протезування знімними пластинковими протезами між частотою МЯ та СХ. На сьогодні оцінка частоти МЯ є загальноприйнятим показником цитогенетичної дії досліджуваних екзогенних та ендогенних чинників [12].

Отже, підсумовуючи дані літератури, бачимо, що у стоматології (і в пародонтології зокрема) вивчалися показники ФСГ букальних епітеліоцитів як окремо, так і водночас, iз показниками НГК, але показники ФСГ букальних епітеліоцитів та лімфоцитів ще не досліджувалися. Показниками АAХ, ХА, МЯ вивчалися у пацієнтів із протезним стоматитом, проте у хворих на ГП вони не досліджу- 
валися. Морфоденситометричні показники у стоматології не вивчені зовсім. У зв'язку $з$ цим, для встановлення нових механізмів етіопатогенезу ГП, доцільно провести поєднане

\section{Список літератури}

1. Юдіна Н. О. Застосування молекулярно-генетичного методу в діагностиці хвороб пародонта у населення Білорусії/Н. О. Юдіна, А. В. Люговська, С. А. Костюк// Вісник стоматології. - 2008. - № 5-6. - С. 49-55.

2. Почтаренко В. А. Изучение влияния генетического полиморфизма человека на особенности течения воспалительных заболеваний пародонта : автореф. дис. на здобуття наук. ступеня канд. мед. наук : спец. 14.00.21 «Стоматологія» / А. В. Почтаренко. - М., 2005. - 23 c.

3. Манущак Н. В. Взаємозв'язок патології пародонта та патології шлунково-кишкового тракту / Н.В.Манущак, Н. В. Чорній, В. В. Шманько // Клінічна стоматологія. - 2011. - № 1-2. - С. 23-27.

4. Терапевтична стоматологія. Захворювання пародонта / Н. В. Данилевский, А. В. Борисенко [та ін.]. К., 2008. - T. 3. -595 c.

5. Мельничук Г.М. Регуляція показників функціонального стану геному у віддалені терміни після комплексного лікування генералізованого пародонтиту / Г. М. Мельничук // Галицький лікарський вісник. - 2011. - Т. 18, № 5 - С. 69-72.

6. Мельничук Г. М. Генералізований пародонтит i пародонтоз: маркери спадкової схильності, патогенетичні механізми метаболічних порушень та їх комплексно корекція : дис. ... д-ра мед. наук : спец. 14.01.22 «Стоматологія» / Г. М. Мельничук. - Одеса, 2008. -452 с

7. Мельничук Г. М. Цитологічні показники інтерфазних ядер соматичних клітин при захворюваннях тканин пародонту / Г. М. Мельничук, Л. Є. Ковальчук, С. С. Мельничук // Галицький лікарський вісник. - 2001. - Т. 8, № 1 - С. 61-64.

8. Соколова I. І. Особливості патогенезу, клініки, діагностики та лікування генералізованого пародонтиту в осіб зі спадковою схильністю до його розвитку : автореф. дис. на здобуття наук. ступеня д-ра мед. наук : спец. 14.01.22 «Стоматологія» / I. І. Соколова. - К. 2008. - 35 с.

9. Зорина О. А. Генетические факторы предрасположенности к развитию агрессивного пародонтита: белки матрикса, матрикмины и их регуляторы / О. А. Зорина, О. А. Борискина, О. А. Леонович // Стоматология. - 2013. - № 1. - С. 76-83.

10. Чернюк Н. В. Клініко-генеалогічний метод в діагностиці хронічного обструктивного бронхіту / Н. В.Чернюк // Архів клінічної медицини. - 2005. № 1(7). - С. 69-71.

11. Дзвонковська В. В. Комплексна діагностика і лікування хворих на виразкову хворобу дванадцятипалої кишки поєднану з хронічним панкреатитом : дис. ... д-ра мед. наук : спец. 14.01 .02 «Внутрішні хвороби» / В. В. Дзвонковська. - Івано-Франківськ, 1999. -326 c. дослідження, яке включає вивчення родоводів, епігенетичних, морфоденситометричних та імуноцитогенетичних механізмів розвитку ГП, а також зміни їх під впливом лікування.

12. Палійчук I. В. Обгрунтування комплексних методів прогнозування, діагностики, профілактики та лікування протезних стоматитів : дис. ... д-ра мед. наук : спец. 14.01.22 «Стоматологія» / І. В. Палійчук. Івано-Франківськ, 2013. - 586 с.

13. Нейко $€$. М. Епігенетичні механізми регуляції активності генів і мультифакторні хвороби / $€$. М. Нейко, Л. Є. Ковальчук, Н. В. Чернюк // Галицький лікарський вісник. - 2007. - № 1. - С. 11-14.

14. Епігенетична регуляція активності генів епітеліальних клітин слизової оболонки носової та ротової порожнини / В. І. Попович, Л. Є. Ковальчук, Н. В. Чернюк [та ін.] // Ринологія. - 2007. - № 1. - С. 14-19. 15. Кукурудз Н. I. Клініко-патогенетичне обгрунтування застосування амізону в комплексному лікуванні генералізованого пародонтиту : автореф. дис. на здобуття наук. ступеня канд. мед. наук : спец. 14.01.22 «Стоматологія» / Н. I. Кукурудз. - ІваноФранківськ, 2008. - 20 с.

16. Кукурудз Н. І. Вивчення порушень функціонального стану геному нейтрофільних гранулоцитів периферійної крові у хворих на генералізований пародонтит та їх корекція амізоном / Н. I. Кукурудз, л. Є. Ковальчук, В. І. Герелюк // Галицький лікарський вісник. - 2006. - Т. 13, № 4. - С. 43-45.

17. Ковальчук Л. $€$. Аналіз функціонального стану хроматину лімфоцитів у хворих на гломерулонефрит при різних стадіях хронічної хвороби нирок із супутньою серцевою недостатністю та без неї / Л. Є. Ковальчук, В. Я. Ястребова // Експериментальна та клінічна медицина. - 2012. - № 2(55). - С. 32-36.

18. Чернюк Н. В. Динаміка морфоденситометричних показників і функціонування хроматину в соматичних клітинах при хронічному обструктивному захворюванні легень / Н. В. Чернюк, С. Б. Геращенко, Л. Є. Ковальчук // Галицький лікарський вісник. 2008. - № 4. - С. 69-71.

19. Чернюк Н. В. Цитогенетичні маркери тяжкості перебігу хронічного обструктивного бронхіту / Н. В. Чернюк // Галицький лікарський вісник. -2004. № 3. - С. 96-99.

20. Палійчук I. В. Визначення спадкової схильності до протезних стоматитів за показниками метафазного аналізу / І. В. Палійчук, Л. Є. Ковальчук // Галицький лікарський вісник. - 2007. - Т.14, № 4. С. $73-75$

21. Ковальчук Л. Є. Цитогенетичне дослідження соматичних клітин бронхоальвеолярної лаважної рідини та слизової оболонки ротової порожнини у хворих на хронічне обструктивне захворювання легень / Л. Є. Ковальчук, Н. В. Чернюк // Вісник проблем біології і медицини. - 2006. - Вип. 2. - С. 50-53.

Отримано 11.10.16 